\title{
Arsenical Copper Production in the Late-Chalcolithic Period, Central Plateau, Iran. Case Study: Copper-based Artefacts in Meymanatabad
}

\author{
Poorya Kashani ${ }^{{ }^{*}}$, Bita Sodaei ${ }^{\mathrm{a}}$, Rouhollah Yousefi Zoshk ${ }^{\mathrm{a}}$, Mehdi Hamivand ${ }^{\mathrm{b}}$ \\ ${ }^{a}$ Department of Archaeology, Varamin-Pishva Branch, Islamic Azad University, Varamin, Iran \\ ${ }^{b}$ Department of Archaeology, Central Tehran Branch, Islamic Azad University, Tehran, Iran
}

\section{ARTICLE INFO}

\section{Article history:}

Received: 23. May 2013

Accepted: 18. December 2013

\section{Key words}

Chalcolithic

arsenical copper

central plateau

chemical composition

\begin{abstract}
$A B S T R A C T$
Four copper-based artefacts and one slag from the Late-Chalcolithic Meymanatabad in the central plateau of Iran were analysed by the Particle-Induced X-Ray Emission (PIXE) method. This study has been carried out in order to characterize the chemical composition of the items under study and come to an understanding of their mineral ores. Through an understanding of these two items, lesser known aspects of metalworking abilities in that space-time grid can be revealed. The analyses made it apparent, that low but significant levels of arsenic $(>1 \mathrm{wt} \%)$ were present in all of the samples. This fact along with the discovery of slags at the site can indicate local work on smelted arsenical copper. This type of copper-base artefact production could be considered a wide practice in the Late Chalcolithic Period in the central plateau of Iran.
\end{abstract}

\section{Introduction}

Tepe Meymanatabad is located in the Tehran province, 25 kilometres south-east of Tehran, 4842935 northern longitude, $805 \quad 1051$ eastern latitude (Figure 1). The mound has a total area of 2.5 hectares and its maximum height is 3 metres. The first season of excavations at Tepe Meymanatabad, headed by Rouhollah Yousefi Zoshk, was conducted in the summer of 2011. Tepe Meymanatabad was primarily occupied during the late Chalcolithic period (Yousefi Zoshk 2011).

The existence of slag in the $4^{\text {th }}$ millennium $\mathrm{BC}$ was an important clue to demonstrate the utilization of smelting processes. These types of slags have been discovered in Tepe Sialk, Tal-I Iblis, Tepe Ghabristan, Arisman and Tepe Zaqeh (Pernika 2004; Nezafati et al. 2008). All of these initial developments were centred on metallurgical rich regions on the Iranian plateau (Pigott 2004). The existence of slags in Tepe Meymanatabad demonstrates that the site can fall into the same category. Metal artefacts have also been found in Tepe Meymanatabad.

The earliest copper use in Iran dates back to native copper utilization in the sixth millennium BC. The mid-

*Corresponding author. E-mail: poorya_kashani@iauvaramin.ac.ir $4^{\text {th }}$ millennium $\mathrm{BC}$ was a period during which the transition process from the use of native copper and pure copper smelting to smelting of copper ores with other elements (antimony, arsenic, lead and nickel) had been taking place. The use of copper developed considerably during the Chalcolithic period. Copper was frequently used to produce artefacts at this time in combination with arsenic in southeast Iran, the Caucasus and Central Asia (Thornton 2010).

Analytical research on ancient metal items is currently a common technique in order to reach an understanding of the specialization of alloy production. Elemental analyses are types of characterization research in the field of archaeometry (Kashani et al. 2013a). This study has been conducted by one of these methods, PIXE spectrometry, to characterize the artefacts. It is worth mentioning that the comparative assessment of chemical compositions could lead to the determination of metal manufacturing processes. Archaeologists, therefore, have a preference for employing chemical and physical techniques in order to identify both the elemental composition as well as the production technology (Rehren, Pernicka 2008). Research on ethnographic analogy is based at present on metal analyses which is also considered a modern area of interest (Thornton, Roberts 2009).

In this work, four copper-base artefacts, including two pins, one awl, and one dagger along with a slag have 


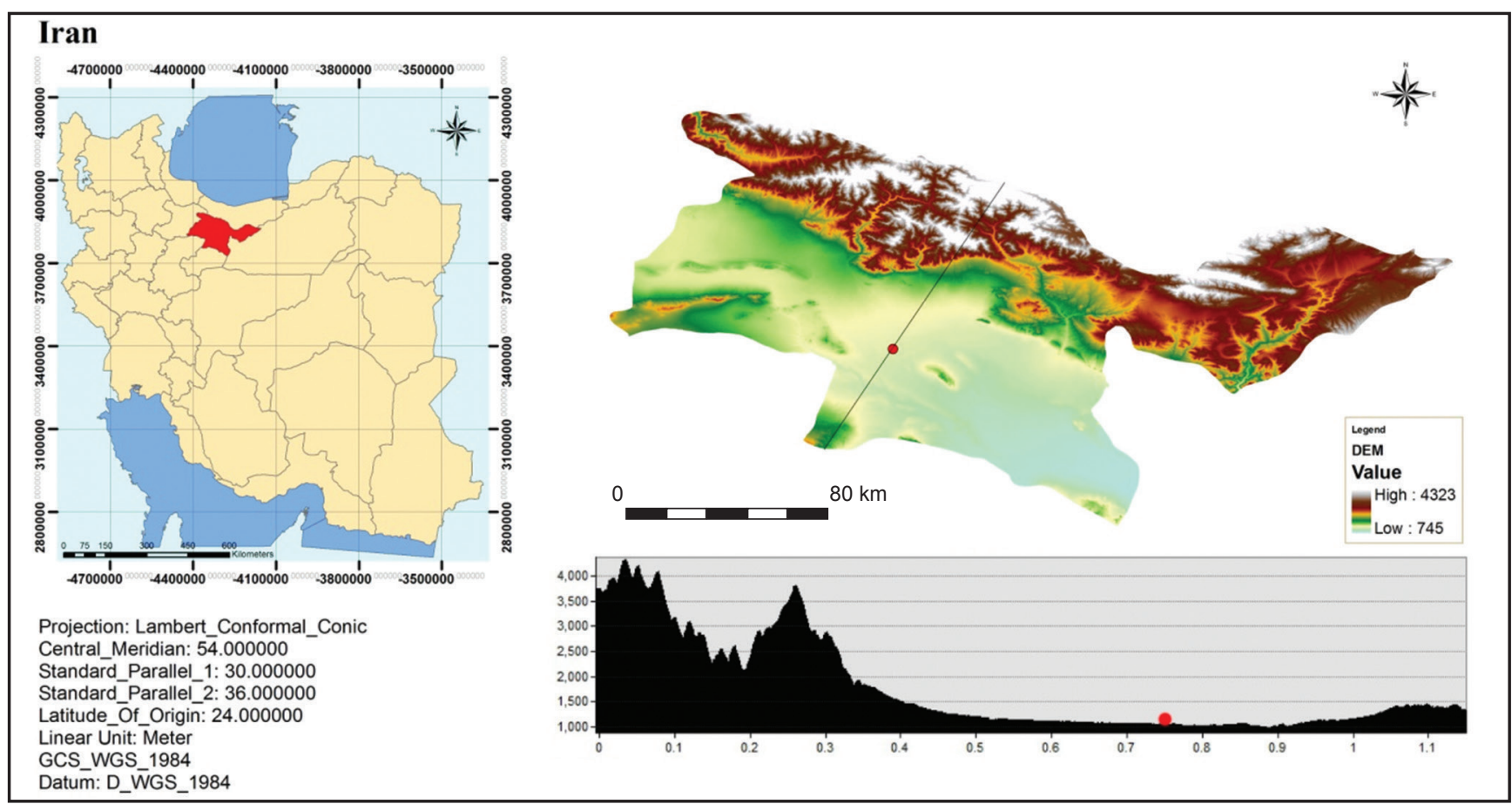

Figure 1. Digital Elevation Model of the Tehran Province and the Location of Tepe Meymanatabad (Yousefi Zoshk 2011).

been analysed to obtain information about the quantitative elemental composition of the metal, mineral ores which have been extracted and the possible metalworking technology of the time which was used to produce the above-mentioned

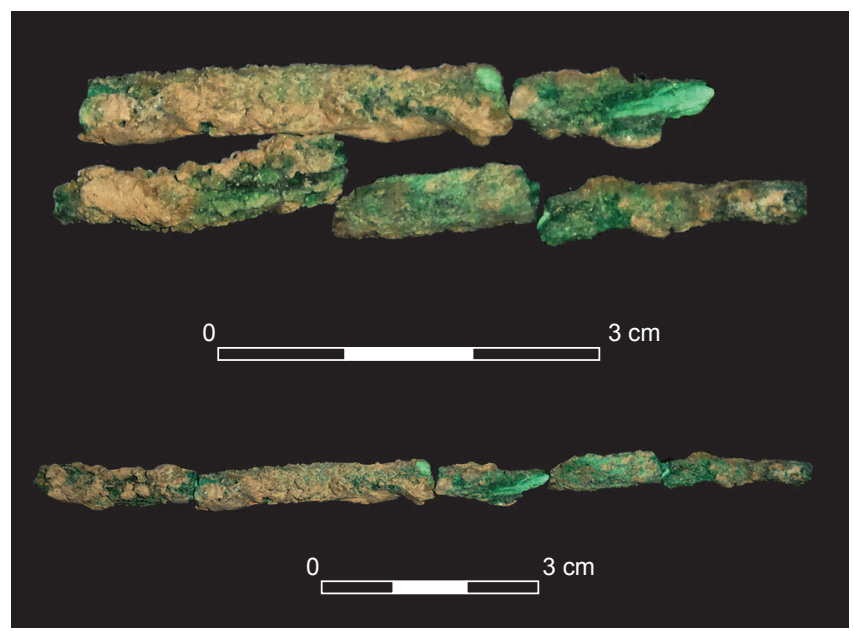

Figure 2. Fragments of a broken copper-base pin (sample code: A), Late Chalcolithic Period, Meymanatabad.

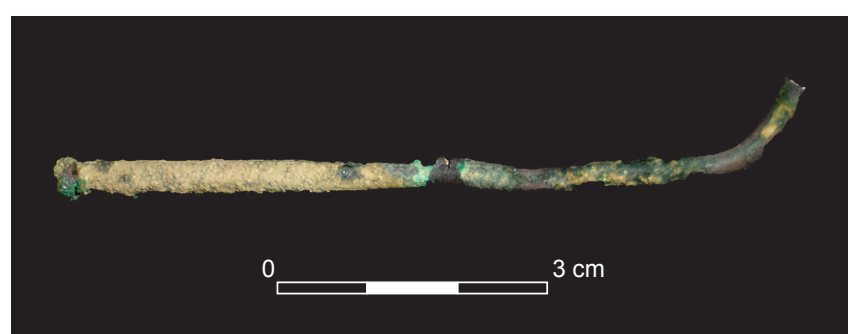

Figure 4. Copper-base bent pin (code: C), Late Chalcolithic Period, Meymanatabad. alloys. Over the course of the study, each object was recorded and marked with a special code. Selected artefacts and sample codes are shown in Figures 2, 3, 4, 5 and 6. Due to the special characteristics of the dagger, two parts of it have been analysed.

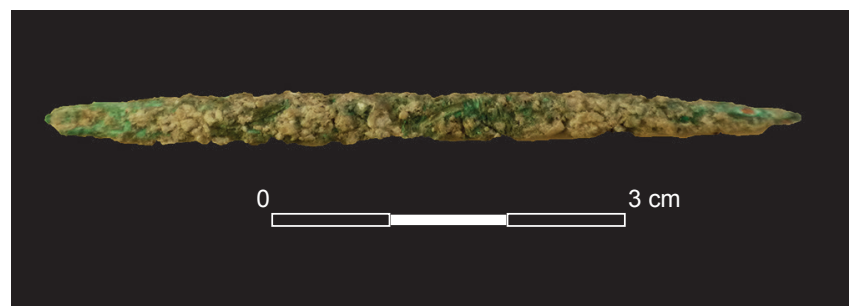

Figure 3. Copper-base awl (code: B), Late Chalcolithic Period, Meymanatabad.

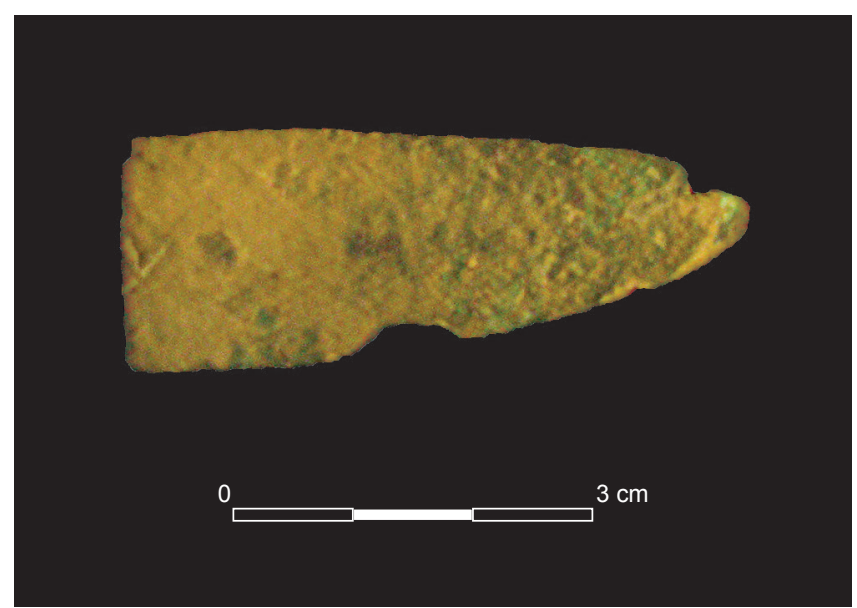

Figure 5. Copper-base dagger (code: $\mathrm{D}_{1}, \mathrm{D}_{2}$ ), Late Chalcolithic Period, Meymanatabad. 


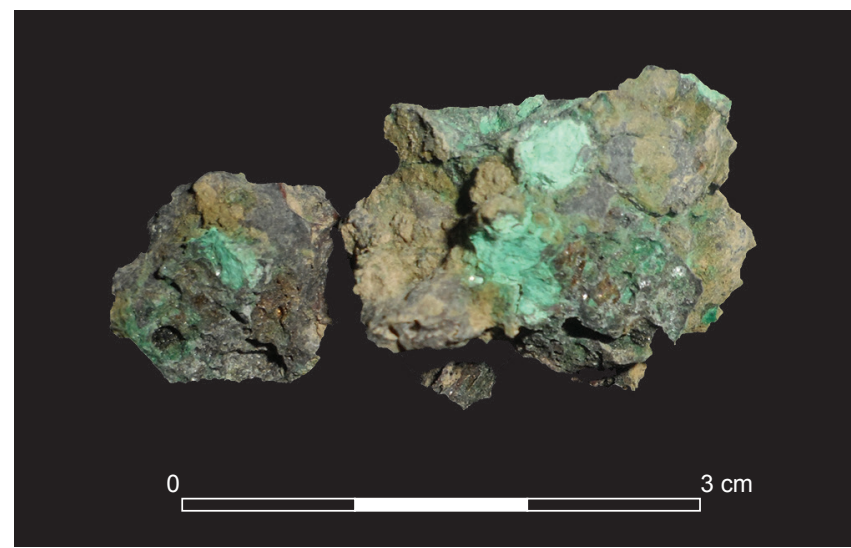

Figure 6. Slag (code: E), Late Chalcolithic Period, Meymanatabad.

\section{Pixe spectrometry}

Concerning the importance of ancient artefacts, it is more preferable to choose a non-destructive technique. Consequently, a PIXE analysis, which is completely nondestructive, plays a significant role in such cases. The fact that PIXE is considered a multi-elemental, fast and sensitive method is an additional bonus which accompanies this advantage (Guerra 1998; Kashani et al. 2013b).

After transferring the samples to the Van de Graaff laboratory of Atomic Energy Organization of Iran (AEOI), spectroscopic studies were carried out on them. Prior to the analysis, the samples were cleaned with a $5 \%$ ethanol solution. A $2 \mathrm{MeV}$ proton beam with a current of 2-3 nA was used to bombard the samples. The samples were consequently inserted into a multipurpose scatter chamber maintained at a high vacuum $\left(10^{-5}\right.$ Torr). The emitted characteristic X- rays were detected with an ORTEC Si (Li) detector (FWHM $170 \mathrm{eV}$ at $5.9 \mathrm{keV}$ ). The GUPIX software was employed to analyse the obtained spectra (Campbell et al. 2000).

\section{Results and discussion}

Based on the results of the analysis, all the studied samples are classified as poly-metal materials. Among the metals, copper appears as the main element. The percentage varies from 87.78 in sample E (slag) to 95.49 in sample D2 (dagger) (Table 1). As is shown in Table 1, the ratio of $\mathrm{Cu}$ in the dagger is much higher than that of the other artefacts.
All of the artefacts contain low but significant levels of arsenic $(>1 \mathrm{wt} \%)$. The amounts of As in the samples are also shown in Table 1. Arsenic is present in a number of coppercontaining mineral ores (Arsenopyrite, Enargite, Olivenite and Tennantite) (Lechtman, Klein 1999), and, therefore, in such cases some contamination of the copper with arsenic would be unavoidable (De Ryck et al. 2005). The significant presence of arsenic in the copper-base artefacts in the chalcolithic period in the central plateau of Iran, where most of the abundant deposits of copper are not arsenic bearing, suggests that this could be an intentional process (Pigott et al. 2003). The arsenic absence in the slag composition (Table 1) puts an emphasis on the intentional Arsenic application to the molten metal mass as a secondary stage in alloy production. Adding Arsenic generally brings about superior strength and durability and improved oxidation resistance during weathering and casting in the final products (Thornton 2010). When considering alloy production processes, one could argue that metalworking in this spacetime grid has been relatively developed and specialized.

Certain elements which are considered components of corrosion products $(\mathrm{Cl}, \mathrm{Si}$ and $\mathrm{Ca})$ have also been observed. The ratio of such elements completely depends on the ratio of the amount of corrosion products. These amounts are relatively high, for instance, in sample A, which is fairly damaged, and in the case of the dagger these amounts are considerably small with no excessive corrosion (Table 1).

As it is demonstrated in Table 1 , the ratio of $\mathrm{Cu}$ in the dagger is much higher in comparison with other items. This could be due to the production of an important artefact, which seems to be more valuable than the others. It is therefore not surprising that in such cases more detailed work will be required.

In addition, $\mathrm{Fe}$ and $\mathrm{Ni}$ were detected in all the samples. $\mathrm{Ti}$ was also observed in four samples (A, B, C and E). When considering the low amounts of these metals $(<0.15 \%)$, it seems probable that these elements are the results of mineral ore impurities.

\section{Conclusion}

Based on the PIXE analysis, it has been concluded that all the samples under study were poly-metals, in which copper was the main element. Corrosion products in the type of chlorides can be seen in all the alloys. When considering

Table 1. Percentage of selected elements by the PIXE.

\begin{tabular}{|c|c|c|c|c|c|c|c|c|c|c|c|c|c|}
\hline Sample & $\mathrm{Cu}$ & As & Si & $\mathbf{K}$ & Cl & $\mathbf{S}$ & Ca & $\mathbf{T i}$ & $\mathbf{F e}$ & $\mathrm{Ni}$ & Mn & V & Others \\
\hline A & 90.85 & 1.73 & 2.91 & 0.87 & 0.84 & 0.68 & 0.74 & 0.10 & 0.96 & 0.17 & 0.05 & 0.06 & Cr: 0.04 \\
\hline B & 90.62 & 1.59 & 3.89 & 0.70 & 0.69 & 0.73 & 0.58 & 0.09 & 0.86 & 0.14 & 0.02 & 0.02 & Mg:0.06 \\
\hline $\mathrm{C}$ & 90.84 & 1.83 & 2.82 & 0.80 & 0.76 & 0.72 & 0.91 & 0.10 & 0.92 & 0.18 & 0.03 & 0.01 & $\begin{array}{l}\text { Cr: } 0.04 \\
\text { Mg:0.03 }\end{array}$ \\
\hline D1 & 94.86 & 1.35 & 0.49 & 0.73 & 0.66 & 0.42 & 0.48 & 0.11 & 0.76 & 0.12 & - & 0.01 & - \\
\hline D2 & 95.49 & 1.36 & 0.41 & 0.56 & 0.46 & 0.31 & 0.44 & 0.10 & 0.77 & 0.10 & - & - & - \\
\hline E & 87.78 & - & 2.70 & 0.25 & 5.29 & - & 0.65 & 0.23 & 2.65 & 0.40 & 0.05 & - & - \\
\hline
\end{tabular}


the detection of arsenic with a relatively constant ratio in all the artefacts and the extent to which the artefacts made of arsenical copper were used in different regions of the Central Plateau and south-east of Iran, it would seem that the making of arsenical copper products had been developed, whether intentionally or unintentionally, into wide practice in the Late Chalcolithic period. Due to the Arsenic absence in the slag composition, it has been concluded, however, that the arsenical application to the alloys at this site might have been an intentional secondary process which can provide an idea as to the relative metalworking specialization in this spacetime grid.

\section{Acknowledgements}

The excavations at Tepe Meymanatabad were made possible by the financial support of Islamic Azad University branch Varamin-Pishva. We deeply appreciate their support. We would also like to extend our thanks to the anonymous reviewers.

\section{References}

CAMPBELL, J. L., HOPMAN, T. L., MAXWELL, J. A., NEZEDHY, Z. 2000: The Guelph PIXE software package III: Alternative proton database. Nucl. Instrum. Methods in Phys. Res. B170, 193-204.

GUERRA, M. F. 1998: Analysis of Archaeological Metals. The Place of XRF and PIXE in the Determination of Technology and Provenance. $X$-ray Spectrometry 27, 73-80.

KASHANI, P., SODAEI, B., HEYDARABADIAN, S., PARANJ, B. 2013a: A Study of Urartian Metallurgy Techniques. Case Study: Urartian Bronze
Weaponry in the Reza Abbasi Museum. Interdisciplinaria Archaeologica, Natural Sciences in Archaeology IV/1/2013, 99-103.

KASHANI, P., KHADEMI NADOUSHAN, F., SHABANI SAMGHABADI, R., ABROOMAND AZAR, P., OLIAIY, P. 2013b: PIXE analysis on Urartian bronze armors and harnesses in the Reza Abbasi Museum, Iran. Mediterranean Archaeology and Archaeometry 13/1, 127-133.

LECHTMAN, H., KLEIN, S. 1999: The Production of Copper-Arsenic Alloys (Arsenic Bronze) by co-smelting: Modern Experiment, Ancient Practice. Journal of Archaeological Science 26, 497-526.

NEZAFATI, N., PERNICKA, E., MALEK SHAHMIRZADI, S. 2008: Evidence on the Ancient Mining and Metallurgy at Tappeh Sialk (Central Iran). In: International Conference AMITEM, Ancient Mining in Turkey and the Eastern Mediterranean. Ankara, Turkey.

PERNICKA, E. 2004: Copper and Silver in Arisman and Tappeh Sialk and the Early Metallurgy in Iran. In: Stöllner, T., Slotta, R., Vatandoust, A. (Eds.): Persias Ancient Splendour; Mining Handicraft and Archaeology. Deutsches Bergbau-Museum Bochum, Germany, 232-239.

PIGOTT, V. C., ROGERS, H. C., NASH, S. K. 2003: Archaeometallurgical Investigations at Malyan, The Evidence for tin-Bronze in the Kaftari Phase. In: Miller, N. F., Abdi, K. (Eds.): “yeki bud, yeki nabud”, Essays on the Archaeology of Iran in Honor of William M. Sumner. The Costen Institute of Archaeology, University of California, Los Angeles, USA.

PIGOTT, V. C. 2004: On the Importance of Iran in the Study of Prehistoric Copper-base Metallurgy. In: Stöllner, T., Slotta, R., Vatandoust, A. (Eds.): Persias Ancient Splendour; Mining Handicraft and Archaeology. Deutsches Bergbau-Museum Bochum, Germany, 28-43.

DE RYCK, I., ADRIENS, A., ADAMS, F. 2005: An overview of Mesopotamian bronze metallurgy during the $3^{\text {rd }}$ millennium BC. Journal of Cultural Heritage 6, 261-268.

REHREN, T., PERNICKA, E. 2008: Coins, Artefacts and IsotopesArchaeometallurgy and Archaeometry. Archaeometry 50, 232-248.

THORNTON, C. P., ROBERTS, B. W. 2009: Introduction: The Beginnings of Metallurgy in Global Perspective. Journal of World Prehistory 22, 181-184.

THORNTON, C. P. 2010: The rise of Arsenical Copper in Southeastern Iran. Iranica Antiqua 45, 31-50.

YOUSEFI ZOSHK, R. 2011: Archaeological Report of Meymanatabad Excavation. MS. Unpublished Report, ICAR. 